\title{
GEO STRATEGI KEBIJAKAN LUAR \\ NEGERI INDONESIA DI ERA JOKOWI \\ DALAM PERSPEKTIF KONTRUKTIVISME
}

\author{
Laode Muhamad Fathun \\ UPN "Veteran" Jakarta \\ Lm_fathun@yahoo.co.id
}

\begin{abstract}
This paper will explain the implementation of geostrategic policy of Indonesian foreign policy in constructivism approach. Constructivism has three basic arguments about identity, norms and language. Another geostrategic position is a way to achieve the objectives of the foreign policy policy of the country.Geostrategy is interpreted by the model of accommodation and corcondance to achieve the desired results. In practice the implementation of Indonesia's foreign policy in crisis Rohingnya show the result that Indonsia proper use of its identity as, democracy, religion and unity. The argumentation is the constitutional and moral and cultural reasons so that Indonesia wants to get involved in the crisis. In the context of Indonesia's engagement norm is any violation of the crisis that occurred in Myanmar is violating international norms as well as national norms due to human rights. On the other hand related to the Indonesian language using the approach of communication with the language of women's diplomacy with women or the diplomacy of heart and heart so as to reduce conflict in Myanmar. The concrete form of Indonesia formulates diplomacy $4+1$ with assistance such as education, economics, relief etc. Thus, hopefully this paper will add to the repertoire of knowledge related to the analysis of foreign policy model of Indonesia.
\end{abstract}

Keywords: Rohingnya Crisis, Myanmar, Indonesia, constructivism, diplomacy $4+1$ 


\section{PENDAHULUAN}

Implementasi kebijakan luar negeri Indonesia terlihat dalam keterlibatan Indonesia dalam tragedi yang terjadi di Rakhine State. Rakhine State yang merupakan negara bagian Myanmar, yang dulu disebut kerajaan Arakan dan etnis Rohingya merupakan warga pribumi di wilayah Arakan, Kasus ini yang terjadi di Myanmar, yakni terjadi kekerasan pada etnis Rohingya sehingga menjadi perbincangan publik internasional. Kekerasan ini dilakukan oleh kelompok Buddha Rakhine State kepada etnis Rohingya yang ke- beradaannya tidak diterima oleh Myanmar akibatnya etnis ini tidak memiliki kewarganegaraan dan kebangsaan.

Kekerasan ini semakin parah ketika pemerintah Myanmar memberi izin untuk diadakan intervensi militer. Akibatnya terjadi kekerasan, kerusuhan, bahkan pembantaian yang dilakukan oleh mereka terhadap para etnis Rohingya yang dilakukan oleh kelompok militer di Rakhine State. Kejadian ini mengakibatkan jatuhnya korban meninggal, luka-luka kepada etnis Rohingya. Dampak nyatanya adalah terjadi mobilisasi etnis Rohingnya yang mengungsi ke negera lain terutama di kawasan
Asia Tenggara. Tragedi ini diperkeruh dengan isu kekerasan diakibatkan karena isu keagamaan yang melibatkan muslim vs Buddha. Etnis ini menjadi minoritas akibatnya penindasan, kekerasan, intimidasi adalah bukan hal yang tabu antara mayoritas dan minoritas. Hal ini sejalan dengan dampak dari sistem pemerintahan suatu negara yang tidak demokratis akan menentukan proses pengambilan kebijakan yang akan dilakukan. Faktanya adalah ketika suatu negara mempersenjatai angkatan militernya dan tidak terkontrol maka secara tidak langsung akan menyebabkan angkatan militer tersebut sebagai monster yang justru akan menjadi instrumen negara dalam menstabilisasi politik domestiknya.

Indonesia terkenal dengan politik bebas aktif dan menjunjung tinggi keadilan, serta Indonesia sangat dipandang di dalam ASEAN sebagai negara yang paling besar diantara negara ASEAN dan mau menjalin hubungan dengan negara lain secara terbuka. Sehingga Indonesia merupakan aktor yang paling tepat dalam menghadapi situasi seperti saat ini, Indonesia diketahui memiliki kedekatan dengan pemerintahan Myanmar sehingga hal ini dapat dijadikan 
media persuasif untuk mengatasi kasus Rohingya dengan adil dan damai.

Dalam prinsip Politik Luar Negeri Indonesia yakni "bebas aktif”, bebas diartikan bahwa Indonesia tidak memihak pada satu blok manapun baik barat maupun timur. Sedangkan aktif berkaitan dengan cita-cita UUD 1945 seperti aktif menjaga ketertiban dunia. Artinya bebas di sini bukan lagi berarti tidak berpihak pada blok ideologi tertentu, tetapi memiliki restorasi makna misalnya bebas dalam arti menjalin kerja sama dengan negara manapun atas nama kepentingan negara. Perlu dibedakan dahulu bahwa Politik Luar Negeri adalah identitas suatu negara yang menjadi ciri khas atau keunikan negara tersebut dalam hubungan eksternalnya atau abstraksi dari negara tersebut yang diambil dari nilai-nilai dan budaya negara itu. Dalam makna lainya Politik Luar Negeri adalah refleksi kebutuhan dari negara yang bersangkutan yang akan dipengaruhi oleh kebutuhan domestik yang sejalan dengan kebutuhan eksternal. Di sisi lainya kebijakan luar negeri adalah strategi yang harus dicapai atau legitimasi dan cara untuk mewujudkan Politik Luar Negeri itu. Dengan demikian, bukan sesuatu yang tabu apabila kebijakan luar negeri setiap pemimpin negara berbeda-beda.

Fokus dari paper ini adalah menganalisa model kebijakan luar negeri Indonesia dengan mengambil sudut pandang konstruktivisme. Pendekatan ini akan menjadi pisau analisis dalam implementasi kebijakan luar negeri Indonesia. Sehingga akan ada korelasi dalam analisis teori kebijakan luar negeri Indonesia dengan menggunakan pendekatan konstruktivisme.

Pemikiran post positivis seperti teori Konstruktivis cenderung baru dalam studi Hubungan Internasional yang baru berkembang pada tahun 2000an di Indonesia. Tokoh seperti Nicholas Onuf adalah pemikir awal konstruktivisme yang berasal dari di Amerika Utara pada dekade 1980an.Pemikiran

konstruktivis memberikan argu-

mntasi dasar"Manusia senantiasa mengkonstruksi, atau membentuk, realitas sosial, bahkan dirinya sendiri” (Onuf, 1989), (Rosyidin, 2015). Lebih lanjut, Alexandar Wendt memberikan argumentasi bahwa konflikadalah sesuatu yang diciptakan dan dikonstruksi oleh negara -negara. Konflik seperti halnya dua sisi mata uang yang tidak terpisahkan dalam suatu fenomena sosial. Wend menga- takan "...Anarchy is what state 
make of it ..". Konstruktivisme berkembang sebagai jawaban atas variabelindependen ,di mana dalam hubungan antara agen dan struktur aktor yang terlibat bukan sebatas Negara.Dalam struktur sosial masih ada aktor lain yang juga berinterkasi. Pemikiran ini juga memberikan argumentasi bahwa fenomena sosial seperti konflik adalah bukan sesuatu apa adanya ( given) tetapi di adakan (take and give). Dalam konteks inilah konstruktivisme berangkat dari kesadaran keseimbangan pemikiran manusia tidakselalu berhubungan dengan maerial tetapi konstruksi ideasional. (Wendt, 1992) (Rosyidin, 2015). Konstruktivis memandang kepentingan sebagai derivasi dari identitas dan norma. Kepentingan bukanlah sesuatu yang terjadi, tetapi akan terus mengalami interpretasi dan reinterpretasi dalam sebuah proses interaksi.

Wendt memberikan arguementasinya bahwa tindakan suatu Negara dalammembentuk anarkisme dalam sisteminternasionaldi dasarkan pada identitas yang dimiliki oleh aktor tersebut. Identitas adalah ke- sadaran aktor dalam memberikan keputusan dalam fenomena inter- nasional. Wendt mengatakan ada empat jenis identitas yaitu identitas personal (atribut personal), iden- titas peran (tanggung jawab), identitas golongan (kategori aktor) dan identitas kolektif (kesamaan). Identitas tersebut kemudian dibagi dalam dua kategori yakni kategori personal ( inter subjektif diri ) dan kategori sosial ( inter subjektif interaksi sosial) (Wendt, 1992).

Bentuk kongkrit dari argumentasi pemikiran konstruktivismeadalah dengan mengutamakan norma untuk mendasari setiap tindakan Negara. Norma internasional menjadi fondasi- dasar untuk mengontrol perilaku- Negara yang anarki. Norma adalah bentuk kesepakatan yang di- bentuk dari identitas sosial aktor untuk menciptakan

perdamaian internasional. Norma menjadi ukuran landasar perilaku Negara yang akan diberikan nilai baikatau buruk.Dengan demikian norma adalah bentukan dalam struktur kesepakatan internasional (norma struktur) dan norma yang telah ada dalam aktor (personal). Menurut Emanuel Adler dan Michael Barnett mengatakan "aktor dapat berbagi nilai, norma dan simbol yang menyediakan identitas sosial, serta melibatkan diri dalam berbagai macam interaksi antar negara yang mencerminkan kepentingan berjangka panjang, hubungan timbal balikdan kepercayaan, yang menyingkirkan kekuatan dan 
ketidak percayaan didalam benak mereka" (Rosyidin, 2015). Nroma menjadi aturan tertulis dan tidak tertulis yang menjadi nilai dasar agar seriapaktor mampu berinteraksi dengan aktor lain sesuai dengan kesamaan pemikiran.Dari kesamaan itulah memunculkan kepekaan untuk membangun Dengan demikian, Fungsi norma dalam konstruktivis, diantaranya Fungsi Regulatif, sebagai pedoman atau penuntut tindakan aktor. Apa yang seharusnya dilakukan dan apa yang seharusnya tidak dilakukan dan fungsi Konstitutif, sebagai peran dalam membentuk identitas dan kepentingan aktor (Linklater, 2005).

Oleh sebab itulah, paper ini akan fokus membedah isu Rohingnya yang terjadi di Myanmar. Dalam sudut pandang konstruktivisme kejadian ini akan dilihat sebagai sebuah konstruksi di mana akan terjadi sebuah pendekatan iden- titassebagai interkasi simbolik. Identitas itu akan menentukan perilaku aktor dalam menentukan tindakannya.Dari identitas itu dalamsatu regionalime ASEAN telah diseepakati bersama tentang norma-norma yang menjadifondasi dasar Negara-negara dalam memberikan i nte $r$ ve $n s$ i ke $m$ anu $\mathrm{s} i \mathrm{a}$ an. Artinya tindakan di dasari oleh kosmopolitanisme identitas regionaldan domestic sehingga akhirnya pendekatan identitas selalu mengutamakan kesadarn berfikirberupa ide kesamaan yang diartikulasikan melalui baha dan komunikasi, Bahsa dan komunikasi inilah yang menjadi instrument dalam menteleaikan masalah Rohingnya yang kemudian disebut dengan diplomasi.

\section{KERANGKA TEORITIK}

\section{TEORI KEBIJAKAN LUAR LUAR NEGERI}

Dalam analisa kebijakan politik luar negeri bisa dilihat dalam berbagai jenis model.Graham Alison menjelaskan model kebijakan politik luar negeri dengan 3 model.

(1) proses ini lebih menekankan pada peran aktor individual dan bersifat intelektual. Artinya proses ini membutuhkan informasi yang sangat baik sebelum mengambil kebijakan dan perlu leadership yang matang, (2) Model organisasi, model ini menekankan pada politik luar negeri pada standar operasi sebuah organisasi artinya proses ini sangat makanistik, (3) model politik birokrasi, model ini lebih beorientasi pada psisi tawar-menawar dan kepantingan kelompok tertentu sehingga disebut sebagai proses politik (Warsito, 1998). Kemudian 
disimpulkan oleh Holsti bahwa kebijakan politik luar negeri sebuah negara terdiri ada empat komponen yakni: (1) orientasi kebijakan politik luar negeri, peran nasional, (3) tujuan dan (4) tindakan (K, 1988). Karena Negara sebagai unit yang mewakili segala kepentingan harus sadar benar seperti yang dikatakan Ricard Snyder dkk tentang how does the international system work and how and why do national actors perform as they do in international relation (McClelland, 1981).

Model adalah skema yang digunakan untuk menganalisis munculnya kebijakan Politik Luar negeri. Model yang dikembangkan oleh William D. Coplin dengan stategi aktor rasional. Model ini berorientasi pada kalkulasi rasional aktor. Model ini bertumpu pada situasi sistem internasional, presepsi aktor, politik elite, kapabilitas Negara serta stategi Negara lain.Prespektif ini merujuk pada (1) leadership strategy yang berkaitan dengan upaya menghilangkan kekerasan dalam setiap masalah kebijakan luar negeri, (2) Concordance strategy mengacu pada upaya saling menguntungkan (3) accommodation strategy artinya keseimbangan ketika ada Negara yang dominan kapabiltasnya, dan confrontations strategy ketika kemampuan suatu Negara meningkat dan tidak bisa diimbangi. Model selanjutnya adalah model incremental. Model ini berasumsi akan ketidakpastian dari situasi lingkungan sehingga, aktor harus melakukan penyesuaian sebelum melakukan pengambilan keputusan (Mas'oed, 1994) Model Wiliam D. Coplin:

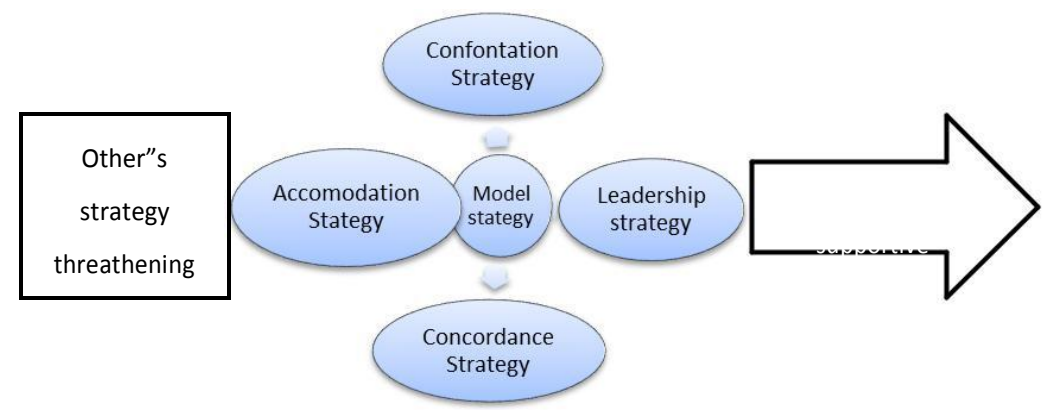

Model ini akan digunakan dalam konteks kelembagaan yakni untuk mencari pola strategi yang Kementrian Luar Negeri (Retno digunakan untuk implementasi Marsudi). Model ini akan kebijakan luar negeri Indonesia melahirkan geostrategi dalam studi 
Hubungan Internasional:

Geostrategy links geography with strategies of war. It places the planning and management of war in the context of geographical, physical, and artificial (man-made) characteristics of the operational region. Geostrategy also demands a precise inspection of the geographical characteristics of an area from the point where military forces deploy until the desired destination. According to Geoffrey Sloan and Colin Gray, geography is "the mother of strategy." (Tovy, 2015).

Menurut Prof. Dr. Dr. K. dalam Modern Geostrategy tahun 2017, Methods and Practice Saalbach skema geostrategi sebagai berikut:

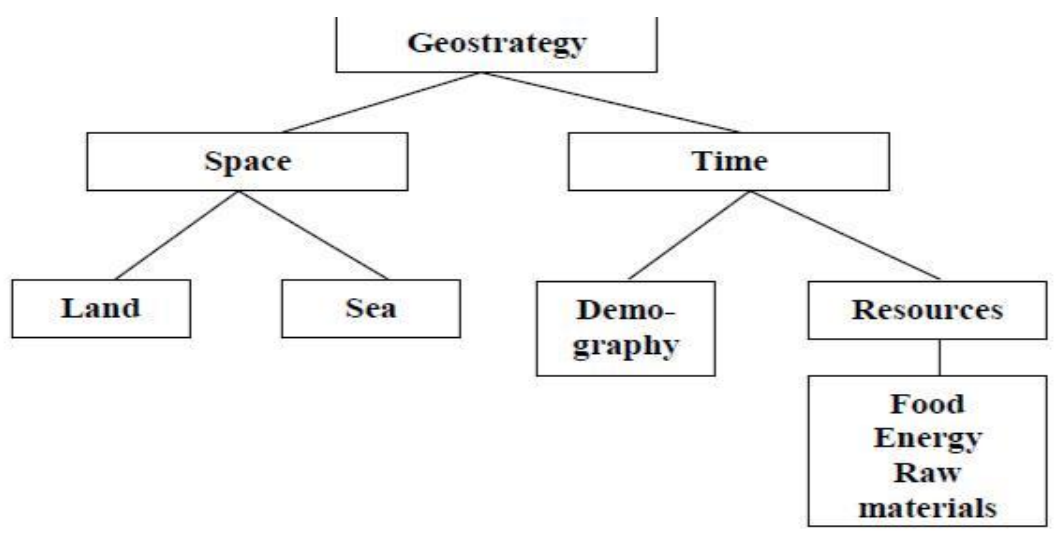

Geostrategi menyangkut tiga menyangkut hubungan antara political pertanyaan yakni pertama siapa kita menyangkut apa yang kita miliki yaitu kapabilitas, integritas atau potensi yang kita miliki yanag sering disebut dengan national power. Kedua, apa keinginan kita menyangkut target capaian atau keinginan yang menjadi saran yang sering disebut dengan national interest serta ketiga, bagaimana mencapai tujuan itu atau dikenal dengan tactics atau dalam konteks lain hubungan antara geografi dan politik sering juga disebut human geography yang prinsipnya

behavior dan psycal features. Sehingga geostrategic adalah cara yang harus ditempuh oleh aktor untuk mencapai keinginananya.

\section{TEORI KONTRUKTIVISME}

Thomas Kuhn mengatakan kegiatan keilmuan diawali dengan penelitian sederhana dan pengumpulan fakta secara acak. Normal science ketika tidak ada lagi perbedaan yang mendasar dan normal scienc seperti jigsaw puzzle atau tekateki silang Lebih lanjut, Karl Popper ilmu berkembang secara 
rasional dan akumulatif ada proses falsifikasi dan penemuan baru. Ilmu HI berkembang dalam tahap-tahap dan setiap tahap didominasi oleh semacam "paradigma". Tema yang utama adalah "keanekaragaman dan ketidaksepakatan". Perkembangan suatu bidang studi berkaitan erat dengan perkembangan bidang studi lain Kuhn: perkembangan suatu disiplin ilmu tidak berjalan secara ajeg (Fathun, 2016).

Perkembangan keilmuan studi hubungan internasional (HI) pendekatan ilmu HI selalu memiliki dinamika. Peirode 4 dekade perdebatan ilmu HI mulai debat pertama Debat 1 1920-1940an yang melibatkan Pendekatan Realis dan Idealis yang fokus pada isu high vs isu low politic yang disingkat isu perang dan damai. Kemudian muncul debat kedua yang melibatkan Tradisionalisme vs Behavioralisme yang terjadi pada tahun 1950an -60an yang dikatakan dengan debat metodologis atau paradigm kualitatif vs kuaantitatif. Kemudian debat ketiga muncul pada tahun 1970an -80an yang berfokus pada munculnya kajian baru berupa debat masing-masing neo yaitu neo realis, neoliberal dan neomarxis. Pada debat terkahir atau debat ke empat adalah merupakan debat penentu di mana muncul pendekatan baru di mana pada sisi positivism menganggap ilmu pemngetahuan berhubungan antara fenomena social berbicara apa adanya atau apa yang seharusnya. Artinya dalam perdebatan positivism dan post positivism berhubungan dengan realitas dunia yang apakah bisa di teliti dengan model ilmu alam atau tidak. Dalam konteks inilah para positivism seperti Realisme/neorealisme, L ib e ra lisme/ne olib era lisme NeoMarxisme (strukturalisme) melawan Konstruktivisme, Teori kritis Feminisme Post struk- turalisme Post kolonialisme, Green politics (Carlesnaes, 2013). Pada debat keempat itu muncul pen- dekatan konstruktivisme yang dipelopori oleh Alexander wendt, Nicolas Onuf dan Kartocwil. Dalam dekade perkembangan pendekatan ini berfokus pada tiga hal dasar yaitu ideasional, normative dan linguistic.

Konstruktivisme ideasional Wendt, Nina Tannewald bahwa sistem ide mengacu pada: 1) sistem ideologis yang dimiliki bersama, 2) keprecayaan normatif (baik tidak)

3. Kepercayaan sebab akibat (efektif dan tidak) 4. Deskripsi kebijakan (program khusus) (Hara, 2011). Dalam pendekatan ini memiliki domain utama bahwa di dunia ini tidak ada yang obyektif, semua 
adalah dikonstruksikan dalam otak manusia, dalam ide manusia. Karena dikonstruksikan manusia maka interaksi yang terjadi interaksi simbolis, sesungguhnya merupakan interaksi antar manusia, antarsubyek, atau istilah sosiologi: inter subyektif meaning. Menurut Wendt, ketika ada proses konstruktif, ada sesuatu yang membuat seseorang bisa me- nentukan kepentingan nya. Contoh kalau saya seorang yang jahat, maka kepentingan saya adalah mengakali orang lain, kepentingan saya menjahati orang lain. Kalau saya orang yang bermoral, orang yang baik, maka kepentingan saya adalah kerja sama. Pada intinya bahwa sesuatu itu dikonstruksikan secara bersama, tidak ada yang obyektif, menjadi dianggap obyektif ketika hal itu dikonstruksikan bersama. Oleh karena itu perhatian konstruktivisme pada proses konstruksinya, bukan pada akibat obyektivitasnya.

Pendekatan konstruktivisme yang lain adalah yang dikemukakan oleh Kartochwill. Menurutnya Institusi itu terbentuk karena kesalahan dimasa lalu dan kesalahan-kesalahan ini bisa membangun Norma. Norma tidak saja bersifat regulatif tetapi juga bersifat konstrukstif. Dalam hal ini norma, bukan berarti norma yang harus dilakukan oleh orang yang bermain catur, tetapi norma yang membentuk orang bermain catur. Menurutnya dunia ini tidak anarchis, krn sesungguhnya banyak sekali norma yang mengatur hubungan antar manusia dan juga hubungan antar negara. Kemudian apapun yang ada di dunia ini asalnya dari pikiran yang kemudian dikomunikasikan dalam bentuk speech, dalam bentuk ungkapan, yang kemudian akan menjadi rule. Communicative Action adalah dua orang berinteraksi untuk membangun satu trujuan bersama dan menghasilkan sesuatu yang baru. Kepentingan tidak didefinisikan lebih dahulu dalam berkomunikasi, dalam berargumentasi.

\section{PEMBAHASAN}

Geostrategi Kebijakan Luar Negeri Indonesia dalam Kasus Rohingnya

Dalam konteks perumusan kebijakan luar negeri di Indonesia disesuaikan dengan dengan nilai nilai dasar nasional yang di ambil dari konstitusi Indonesia. Konstitusi Indonesia yaitu UU/37/1999 mengatur bahwa Politik Luar Negeri adalah kebijakan, sikap, dan langkah Pemerintah Republik Indonesia yang diambil dalam melakukan hubungan dengan negara lain, 
organisasi internasional, dan subyek hukum internasional lainnya dalam rangka menghadapi masalah internasional guna mencapai tujuan nasional (pasal 1 (2). Lebih lanjut, pada Pasal 3, Politik Luar Negeri menganut prinsip bebas aktif yang diabdikan untuk kepentingan nasional. Dilanjutkan pada Pasal 4, Politik Luar Negeri dilaksanakan melalui diplomasi yang kreatif, aktif, dan antisipatif, tidak sekadar rutin dan reaktif, teguh dalam prinsip dan pendirian, serta rasional dan luwes dalam pendekatan. Indonesia sebagai negara yang merdeka dan berdaulat, pelaksanaan hubungan luar negeri dan Politik Luar Negeri didasarkan pada asas kesamaan derajat, saling menghormati, saling menguntungkan, dan saling tidak mencampuri urusan dalam negeri masing -masing, seperti yang tersirat di dalam Pancasila dan Undang-Undang Dasar 1945 (Pasal

2). Dengan demikian, konteks kebijakan Politik Luar Negeri Indonesia harus didasarkan pada konstitusi dasarnya yaitu UUD 1945 dan Dasar negara yakni Pancasila disertai dengan sikap-sikap yang menguntungkan Indonesia vebagai negara merdeka dan saling menghormati untuk mencapai tujuan masing-masing negara yang ditempuh melalui diplomasi.
Sejalan dengan itu Ricard W menjelaskan bahwa merupakan konversi input berupa infromasi tentang apa yang harus dilakukan sebuah negara menjadi output berupa diplomasi atau aliansi/ kualisi (2012:411). George Kennan mendefinisikan diplomasi sebagai "an art and international relations in a universal context (Fathun, Paradiplomasi Menuju Kota Dunia: Studi Kasus, 2016). Jadi dapat disimpulkan bahwa diplomasi merupakan upaya negara melalui cara berkomunikasi yang baik dengan wakil-wakil yang terpilih untuk merebut kepentingan nasional dengan jalan damai. Dalam prakteknya diplomasi cenderung diarahkan pada metode negosiasi. Namun, menurut penulis memaknai diplomasi tidak sesempit definisi di atas. Penulis menympulkan ada kurang lebih 300 definisi tentang diplomasi, namun diplomasi diarahkan pada metode komunikasi, negosiasi, dan triki dalam konteks yang berbeda.Diplomasi bukanlah media yang tunggal. Diplomasi adalah artikulasi dari implementasi kebijakan luar negeri suatu negara. Diplomasi adalah salah satu cara mewujudkan kebijakan luar negeri.

Diplomasi sebagai media untuk mewujudkan implementasi kebijakan luar negeri Indonesia 
terbukti pada kasus pembantaian etnis Rohingnya di Myanmar. Pada dasarnya keterlibatan Indonesia dalam kasus kekerasan etnis tersebut dapat di analisis menggunakan pendekatan konstruktivisme yaitu pendekatan ini menekankan pada tiga variabel kunci yakni identitas, norma dan bahasa.

\section{Variabel pertama terkait identitas} menyangkut atrbut nasional. Kebijakan Politik Luar Negeri Indonesia yang terlibat dalam kasus Rohingnya tidak terlepas dari identitas Indonesia sebagai Negara beradab. Beradab diukur dari identitas konstitusional, identitas moral (agama) dan identitas HAM. Atribut nasional sebagai sebuahidentitas menyaangkut dengan peran nasional baik berupa aktor individual maupun aktor lem- baga. Keterlibatan Indonesia dalam kasus tersebut membawa aktor Menteri Luar Negeri Indonesia Retno Marsudi untuk melakukan intervensi kemanusiaan. Keter- libatan tersebut di dasari oleh kepekaan dan keprihatinan Indonesia terhadapkasus tersebut. Artinya ada studi pebandingan antara pengelolaan Negara di Indonesia dengan Myanmar. Pengelolaan Negara yang buruk di Myamar menjadikan dampak burukterhadap warga Myanmar itu sendiri. Konteks yang sama Indonesia pernah mengalami masa lalu terait pengelolaan Negara yang tidak manusiawi bai itu peritiwa G30SPKI, dan reformasi 1989.

Perbandingan masa lalu membuat kepekaan sehingga menjadi dilemma bahwa tindakan tidak manusiawi tidak sessuai dengan konstitusi Negara manapun. Faktualnya adalah untuk Hak Asasi Manusia sendiri dalam UUD 1945 diatur dalam Pasal 27 sampai dengan Pasal 31, tetapi yang berintikan hak untuk beragama terdapat dalam dua pasal diatas yaitu Pasal 28 E dan Pasal 29. Lebih lanjut tertuang UU No. 39 tahun 1999 tentang Hak Asasi Manusia Pasal 22 ayat 1 dan 2 bahwa negara menjamin setiap warganegaranya untuk memeluk agama dan kepercayaanya masingmasing dan merdeka dalam menjalankan ibdahanya masingmasing.Pada pasal 24 nya bahwa setiapwarga egara berhakuntuk bebas dalam melaksanakan rapat, berkumpul dengan maksud-maksud damai. Konteks ini relevan juga dengan pasal 29 ayat 1 dan 2 UUD 1945. Disisilainya pasal 28 E di anjurkan tentang setiapwarga negara juga berhak untuk mendapat peangajaran yang layak, bertempat tinggal, dan mendapatkan pekerjaan di bumi NKRI.Bukan hanya itu 
konstitusi juga mengatur kebebasan mengeluarkan pendapat sesuai hatai nurani, berserikat dan berkumpul. Konteks ini tidakterlepas pula dari artikulasi nilai Pansaila yakni sila (1) mengaitkan Negara untuk melindungi kebebasan beragama, sila ke (2) mengaitkan Negara untuk selalu berlaku adildan berdab kepada warga negaranya, sila (3) mengharuskan Negara untukselalu toleran dan menjaga khebinekaan dengan menjaga persatuan ,sila ke (4) mengharuskan komunikasi dalamkonteks NKRI selalu mengutamatak musyawarah dan silake

(5) kemampuan Negara untuk menyediakan sumber-sumber kehidupan yang layakbagi warganya.

Orientasi dasar kebijakan politik luar negeri Indonesia adalah Pancasila dan Konstitusi Negara. Dengan argumentasi dasar nila-nilai dasar pancasila membuat Indonesia harus terlibat dalam kasus tersebut. Artinya ada perbandingan di mana Indonesia merasa cukupmampu berbuat untuk mengatasi krisis kemanusiaan di Myanmar. Argumentasi konstitusional menjadi nilai dasar identitas personaldan dan identitas moral (agama) dalam keterlibatan Indonesia di Myanmar. Dalam konteks lain Indonesia dalam bentuk identitas golongan atau identitas ciri khas
Negara, di mana Indonesia adalah Negara yang memiliki system politikdan pemerintahan demokrasi Pancasila dengan memberikan kebebasan bertanggung jawab dalam pengelolaan Negara terutama kolaborasi antara Negara dan warga Negara. Dalam kaidah lain Indonesia adalah Negara yang beragam sehingga menjaga persatuan begitu penting untuk menjaga stabilitas Negara. Melihat faktanya di Myanmar hal tersebut bukan hanya menggangu stabilitas Myanmar namun regionalism ASEAN pula. Identitas sebagai Negara memiliki adab adalah domain penting dalamketerlibatan Indonesia dalam kasusini.

Lebih lanjut, dalam identitas peran, menyangkut dua hal yakni peran vertikal dan horizontal. Kondisi ini sekaligus kombinasi dari identitas personal Menteri Luar Negeri Indonesia sebagai seorang perempuan sebagai peran horizontal. Menteri Luar Negeri adalah menggunakan diplomasi sebagai model komunikasi. Karena sasaran media komunikasi adalah wanita yaitu (pemimpin de-facto Myanmar) Aung San Suu Kyi maka diplomasi yang terjalin adalah diplomasi antar perempuan. Dalam konten inilah pendekatan konstruktivisme itu masuk di mana 
jiwa keperempuanan bisa menjadi aktor yang mampu menyelesaikan masalah dengan hati. Karakter wanita ketika berkomunikasi adalah selalu mengedepankan keibuan, batiniah, dan yang paling penting adalah kepekaan serta berkomunikasi dengan hati. Salah satu karakter berkomunikasi dalam tradisi melayu adalah ber- komunikasi dengan hati. Orang melayu menganggap hati sebagai benda yang suci dan penenang dan mampu mengurai masalah dengan baik tanpa emosiaonal (Venus, 2015). Di sinilah kaum feminism mengatakan bahwa masalah politik internasional seharusnya melibatkan wanita sebagai bagian dalam menyelesaikan masalah. Wanita janga dianggap sebagai subordinasi yang tidak mampu berbuat apa-apa. Justru dengan pendekatan wanita dalam menyelesaikan masalah akan lebih efisien. Faktanya adalah kaum feminisme mengatakan bahwa kekerasan terjadi baik itu berupa konflik, perang, penindasan dikarenakan perilaku laki-laki yang agresif. Laki-laki adalah sumber masalah internasional dan tidak semua laki-laki pula bisa menyelesaikan masalah itu dengan mudah. Dengan pendekatan feminism justru akan membuat diplomasi hati dengan hati akan semakin terbuka di mana sensitifitas merasakan empati lebih terasa bagi perempuan (Venus, 2015). Hal ini sudah menjadi kodrati dibandingkan laki-laki. Menteri Luar negeri Indonesia yaitu Retno Marsudi menanggapi hal ini sebagai isu yang tidak sesuai dengan prinsip kemanusian. Sehingga, konteks ini sejalan dengan sila kedua yakni Kemanusiaan yang adil dan beradab. Identitas peran vertikal yang dilakukan Menteri Luar Negeri Indonesia adalah menyampaikan kepada PBB terkait pelanggaran HAM yang terjadi di Myanmar. Salah satu buktinya adalah perwakilan PBB untuk Komisi HakAsasi Manusia menyampaikan agar bentuk kekerasan di Myanmar untuk segera dihentikan dan Indonesia sebagai mediator untuk sesegera mungkin mengimplementasikan semua hasil komunikasinya dengan Aung San Suu Kyi. Dukungan perwakilan PBB ini sebagai bentuk citra positif Indonesia dalam mendukung perdamaian dunia yang sesuai dengan amanat konstitusinya. Kasus Rohingnya menjadi bukti kongkrit bahwa keterlibatan Mentri Luar Negeri Indonesia sebagai mediator adalah bukti kepedulian Indonsia yang demokratis dan respekakan komunitas ASEAN. Sehingga, dalam analisis model kebijakan 
luar negeri yang dimainakan oleh Menteri Luar Negeri menggunakan pendekatan geostrategi diplomasi.

Konteks identitas juga berhubungan dengan identitas kolektif. Pemikiran identitas kolektif bias menjadi salah satu variabel keterlibatan- Indonesia dalam intervensi di Myanmar. Identitas kolektif memiliki empat variabel (Hara, 2011) yakni comment fate, interdependency, homogeneity, dan self restraint Konsepini terfaktualisasi melalui sejarah hubungan Indonesia dan Myanmar yang sudah sejak lama sebagai sebuah identitas kolektif baik sejak menjadi bagian dalam Konfrensi Asia Afrika maupun saat ini ASEAN dan beberapaorganisasi internasional lainya.Konsep ini berhubungan dengan Faktor kosmopolitansime, hubungan baik antara kedua negara yang sudah terjalin sejak lama. Hubungan bilateral antara Indonesia dan Myanmar sudah terhitung sejak pembentukan Konfrensi Asia Afrika (KAA) pada 28 april-02 Mei 1954 yakni konfrensi kolombo atau konfrensi lima negara pertama. Kolombo merupakan ibu kota dari Srilangka, di mana lima negara tersebut adalah Perdana Menteri Pakistan: Muhammad Ali Jinnah Perdana Menteri Sri Lanka: Sir John
Kotelawala Perdana Menteri Burma (Myanmar): Perdana Menteri Indonesia: Ali Sastroamijoyo ,Perdana Menteri India: Jawaharlal Nehru. (L.M.Fathun, 2017).

Pada tanggal 18-24 april 1955 dilaksanakanlah konfrensi Asia Afrika pertama di Kota Bandung dengan menghadirkan 29 negara anggota peserta dengan komposisi panca negara yakni Indonesia, Pakistan, Srilangka, India, dan Myanmar menjadi Negara yang mengundang sejumlah utusan wakil lainya seperti 6 negara Afrika dan 18 negara meliputi Asia (Thailand, Filipina, Kampuchea, Vietnam Selatan, Nepal, RRC, Laos, Jepang, Vietnam Utara, Irak, Saudi Arabia, Syria (Suriah), Turki, Yaman), Yordania, Lebanon, Afghanistan, Iran, dan Afrika (Mesir, Liberia, Libia , Sudan, Pantai Emas/Gold Coast, Etiopia). Seperti yang telah dideskripsikan di atas bahwa Negara-negara Asia dan Afrika ini ingin melakukan sumbangsi perdamian internasional (L.M.Fathun, 2017).

Kemudian, Konfrensi Asia Afrika yang dilaksanakan di Bandung dan Jakarta pada tanggal 19 sampai 23 april 2015 sekaligus memperingati 60 tahun kerja sama konfrensi Asia Afrika. Konfrensi tersebut mengundang 109 perwakilan Negara dan 25 
organisasi internasional, dengan meningkatkan kerja sama selatanselatan untuk menciptakan kesejateraan dan pedamaian. Hubungan kosmopolitanisme ini mengandung Deontological / sesuai aturan (rule based). Pendekatan ini berasumsi pada pembuat kebijakan luar negeri interaksi politik luar negerinya akan mengacu pada aturan - aturan yang ada, dengan pendekatan ini seorang aktor akan lebih berfokus kepada hukum yang ada dalam mencapai kepentingan nasionalnya, dan akan lebih menghormati- serta menjunjung tinggi etika dalam berpolitik luar negeri. Faktanya adalah menyadari pentingnyakonfrensi tersebut hubungan antara Indonesia dan Myanmar ada beberapa hasil konfrensi yakni

(1) menghormati hak-hak dasar manusia, tujuan, serta asas yang termuat dalam Piagam PBB; (2) menghormati kedaulatan dan integritas teritorial semua bangsa;

(3) mengakui persamaan ras dan persamaan semua bangsa, baik bangsa besar maupun bangsa kecil;

(4) melakukan intervensi atau ikut campur tangan dalam persoalan dalam negeri negara lain; menghormati hak-hak tiap bangsa untuk mempertahankan diri, baik secara sendirian maupun secara kolektif sesuai dengan Piagam PBB; (6)a) tidak menggunakan peraturanperaturan dari pertahanan kolektif untuk bertindak bagi kepentingan khusus salah satu negara besar; b) tidak melakukan tekanan terhadap negara lain; (7) tidak melakukan tindakan atau ancaman agresi ataupun penggunaan kekerasan terhadap integritas teritorial atas kemerdekaan politik suatu negara; (8) menyelesaikan segala perselisihan internasional secara damai sesuai dengan Piagam PBB; (9) memajukan kepentingan bersama dan kerja sama inter- nasional; (10) menghormati hukum dan kewajiban internasional lainnya.Konfrensi tersebut dikenal dengan sepuluh dasasila bandung atau bandung declaration. "Let a new Asia and a new Afrika be born "bunyi pidato Bung Karno tahun 1955 (L.M.Fathun, 2017).

Lebih lanjut, Konfrensi tingkat pejabat tinggi dengan agenda menjadi bahasan adalah menelaah kembali dasasila bandung yang sudah dituliskan sebelumnya,

(b) meningkatkan kembali kerja sama strategis Negara-negara Asia Afrika, serta (c) mendukung deklarasi kemerdekaan Palestina. Pada poin (b) memiliki tiga pilar utama yakni (1) menyangkut komitmen politik untuk mendukung palestina menjadi 
negara, reformasi PBB, perdamaian internasional serta penguatan kerja sama regional kawasan. Dengan demikian, telah menjadi fakta bahwa hubungan antara Indonesia dan Myanmar sudah terjalin erat baik dalam kerangka bilateral maupun multi lateral. KAA adalah konfrensi yang menghasilkan kesepakatankesepakatan bersama untuk ditaati bersama baik dalam konteks regional dan bilateral. Dengan umur 60 tahun KAA setiap negara baik Indonsia maupun Myanmar telah sepakat dalam 10 poin dasar KAA 1954 dan dan tiga poin KAA tahun 2015. Konfrensi tersebut seharusnya menjadi dasar utama bagi setiap negara di ASEAN maupun anggota KAA untuk selalu aktif menjaga perdamaian dan mengutamakan diplomasi sebagai media untuk menyelesaikan masalah (L.M.Fathun, 2017).

Paradigma kosmopolitansime (deontology approach) sebagai sebuah bentuk identitas kolektif memikiki dua makna yaitu Pendekatan Deontological / sesuai aturan (rule based) dan Pendekatan Consequentialist / Tujuan dan hasil yang akan dicapai (ends-based). Kontekstualnya dalamkasus Rohingnya apa yang dilakukan oleh Menteri Retno merupakan kombinasi dau pendekatan ini. Di mana dengan argumentasi dasar bahwa sebuah tindakan kebijakan harus di dasarkan pada rule based atau ada aturan moralitas yang membenarkannya baik dalam konteks aturan domestikmaupun aturan internasional. Begitu halnya dengan end based dampak buruk atau konsekuensi dari krisis Rohingnya bukan hanya berdampak pada Negara tersebut namun stablitas regionalism ASEAN. Dampak kemanusiaan seperti pemerkosaan, pembunuhan, keke- rasan, pembakaran rumah tidak sesuai dengan deontolgis yanag berlaku dalam hubungan antar Negara.

Dampak krisis tersebut misalnya dikutip dari BBC.Indonesia per tanggal $16 \quad$ september 2017 menuliskan ada sekitar 123 ribu pengungsi Rohingnya yang telah meninggalkan Rakhine sejak 25 Agustus. Badan pengungsi PBB, UNHCR, mengatakan bahwa ada sekitar 5.200 warga Rohingya melarikan diri ke Bangladesh yang jumlahnya mencapai sekitar 620 ribu orang (Kompas.com/25/11//2017) dan sekitar 18.500 orang Rohingya dan kebanyakan perempuan dan anakanak - telah menyeberang masuk Banglades dan sekitar

25 ribu anak-anak mengalami gizi buruk. Mereka menyebrang 
ke Banglades dalam kondisi kelaparan (Kompas/10/11/2017) dan bahkan sudah ada sekitar 12.000 pengungsi Rohingya di Indonesia. yang paling parah justru India melakukan deportasi 40.000 pengungsi Rohingya, karena dianag- gap sebagai imigran ilegal. Berita terbaru dikutipdari Kompas. com/02/02/2018 menuliskan bahwa pada akhir 2017 terjadi genosida erhadap etnis Rohingnya dengan bukti investigasi dari AFB bahwa terdapat lima kuburan masal di Rakhine. Sebelumnya Myanmar telah bertanggung jawab ketika ditemukan fakta ada penguburan massal yang berisi 10 jenazah. Video Associated Press memberikan informasi bahwa upaya penggunaan asam untuk memusnahkan jenazahjenazah itu.

Fakta lainya adalah dikutip dari Tribun Jabar.co.id September 2017 Biksu Buddha Asin Wirathu sebagai pemimpin penggerak kekerasan di Rakhine terhadap etnis Rohingnya. Asin Wirathu merupakan pemimpin kontroversial kelompok 969 yang menolak perluasan wilayah Islam di Myanmar. Asin Wirathu juga dijuluki oleh majalah Time sebagai The Face Buddish Terror sebagai militant yang anti Islam. Asin Wirathu juga menyatakan bahwa Islam adalah ancaman besar bagi
Buddha dengan mengambil sampel Indonesia yang dahulu adalah beragama Hindu Budha.

Dengan landasan moralitas dalam etika kosmopolit disebut dengan act -deontologi - tindakan pemerintah Myanmar seharusnya mengutamakan kepentingan umat manusia yang dilandaskan dengan sikap dan moralitas dalam menghargai hak asasi manusia. Seharusnya pemerintah Myanmar dapat menyelesaikan konflik ini tanpa kekerasan dengan membangun dialog antarkaum Buddha Rakhine dengan etnis Myanmar untuk menyelesaikan konflik dengan damai, bukan dengan cara kekerasan mengusir serta membunuh kaum Rohingya. Kosmopolit melahirkan kepekaan terhadap moralitas, etika dan kasih sayang. Demikianlah apa yang dipraktekan oleh Menlu RI yang berlatar belakang islamis, seorang perempuan dan tidak lupa pernah menjadi Dubes di Belanda yang tergolong sebagai negara dengan menjunjung etika, dan moralitas serta demokrasi yang baik. Sejumlah faakta itulah menjadikan pendekatan yang dilaukan oleh Menlu RI berhasil dalam diplomasi Indonesia terhadap Myanmar.

Variabelanalisis pandangan kontruktivisme- adalah dari tokoh Kartocwill yang memiliki 
argumentasi dasar bahwa hubungan internasional harus di dasari oleh norma baik tertulis atau tidak tertulis yang menjadi fondasi bertindak setiapnegara dalamkebijakan politik luar negerinya. Dalam hal ini tentunya akan berpengaruh ketika terjadi benturan antara intervensi terhadap konflik dalamsuatu re- gionalesmedan kedaulatan Negara tersebut.Artinya ada rivaalitas antara dampak konflik dan kon- sekuensi politissebagai sebuah entitas kedaulatan.

Lebih lanjut, Faktor kedua adalah ideologi. Lingkungan strategis ASEAN sebagai lingkaran konsentris pertama memiliki pegaruh terhadap pendekatan budaya serta ideologi serta tekanan dalam negeri berupa penindasan terhadap etnis Rohingnya sebagai isu Buddha vs muslim. Kennet Boulding bahwa manusia terkadang tidak bertindak atas fakta-fakta yang objektif, tetapi manusia bertindakberdasarkan situasi. Artinya presepsi tentang dunia menentukan- perilaku (Masoed, 1989:19). Di sini menganut asumsi bahwa interpretasi dunia yang salah akibat doktrin akan mempengaruhi psikologis yang serasa berempati tentang dunia yang dikonstruksi menjadikannya tidak sesuai apa adanya. Holsti menjelaskan bahwa citra merujuk pada tindakan yang dilakukan oleh pembuat kebijakan berupa gambaran tujuan yang akan dicapai dalam situasi tertentu dan tindakan yang akan diambil serta melihat tantangan dari situasi tersebut. Artinya citra menyangkut tentang bagaimana merubah, mempengaruhi tindakan aktor lain terhadap apa yang digambarkan oleh pengambil kebijakan. Sehingga, berproses pada keyakinan dan sikap yang akan diambil oleh sejumlah aktor apakah mendukung, membantu atau menolak.

Konflik yang terjadi Myanmar adalah bentuk penindasan agama mayoritas terhadap agama minoritas. Faktanya dari cuitan pejabat Istanbul dalam tweeternya Perdana Mentri Turki. Artinya pernyataan ini menunjukan bahwa konflik agama adalah faktor terjadinya kekerasan disana walaupun PM tersebut menyebarkan fotohoax yang menurut Philips Vermonte harus ada verifikasi berita agar tidak memperkeruh masalah. Nmun fokus dari tweet ini adalah memfaktualisasi bahwa kekerasan agama merupakan salah satu faktornya.

Andi Wijayanto menjelaskan bahwa pendekatan penyelesaian terhadap masalah kemanusiaan (sipil) menyangkut tiga hal dasar 
yaitu Humanisasi di mana aktor yang menyelesaikan masalah dianggap menjual perang demi kemanusiaanMaksudnya adalah Negara menggunakan isu stablitas dalam negeri untuk melakukan intervensi, termasuk intervensi militer. Apa yang terjadi di Myanmar juga atidak lepas dari aktivitas militer tentara Myanmar. Intervensi militer yang dilakukan oleh tentara Myanmar merupakan bentuk dari kepercayaan Negara untuk memberikan kekuasan tertinggi kepada militer untuk mengontrol stablitas. Akibatnya ketika tidak terkontrol militer akan menjadi monster terhadap sipil. Hal ini tidak sejalan dengan konvensi Den Haag tahun 1899 dan 1907, Konvensi Jenewa 1864, 1906 dan 1949 serta Deklarasi Petersbrug 1868.

Kemudian Hak Asasi Maanusia, apa yang dilakukanoleh tentara Myanmar, para Biksu Maupun Aung San Su Kyi adalah bentuk pelanggaran terhadap konvensi HAM terkhusus piagam PBB pasaal 1(55),(56). Selain itu melanggar Deklarasi HAM 1948 serta Prokol II Konvensi Jenewa. Lebih lanjut, Resolusi Majelis Umum PBB 47/135 tanggal 18 Desember 1992 Declaration on The Rights of Persons Belonging to National or Ethnic, Religious and Linguistic
Minorities menyebutkan hak khusus bagi kelompok minoritas dalam kasus ini adalah etnis Rohingya yang tidak diberikan kebebasan untuk beragama. Deklarasi ini mengatur tentang perlindungan negara atas eksistensi dan identitas kebangsaan, suku bangsa, budaya, agama dan bahasa mereka, hak untuk menganut dan menjalankan agama mereka, hak untuk berpartisipasi dalam kehidupan agama mereka, hak untuk mendirikan dan mempertahankan perkumpulan mereka sendiri, hak untuk melaksanakan hak mereka tanpa diskriminasi, baik secara individu maupun dalam masyarakat dengan anggota-anggota lain dalam kelompok mereka.

Masalah pembersihan etnis secara khusus dituangkan dalam Resolusi Majelis Umum PBB 260 A (III) 9 Desember 1948, Convention on the Prevention and Punishment of the Crime of Genocide. Dalam kasus Rohingya ini, pemerintah Myanmar telah terbukti melakukan hal-hal yang disebutkan dalam Pasal 2 Convention on the Prevention and Punishment of the Crime of Genocide dan Pasal 5 Statuta Roma. Di mana pemerintah Myanmar telah melakukan tindakan yang dapat menyebabkan punahnya sebagian atau keseluruhan anggota etnis Rohingya, seperti membunuh 
anggota-anggota etnis Rohingya, merusak jasmani atau mental anggota -anggota etnis Rohingya, dengan sengaja mengakibatkan penderitaan pada kondisi kehidupan etnis Rohingya yang diperkirakan menimbulkan kerusakan jasmani seluruhnya atau sebagian.

Berdasarkan Pasal IV dan VI Konvensi Pencegahan dan Hukuman atas Kejahatan Genosida mengatakan bahwa Orang-orang yang melakukan pemusnahan suatu bangsa dengan sengaja atau sesuatu perbuatan lain yang disebutkan dalam pasal III harus dihukum, apakah mereka penguasa yang bertanggung jawab secara konstitusional, pejabat, maupun perorangan. Serta dapat diperiksa oleh pengadilan yang berwenang dari negara di wilayah tempat tindakan itu dilaksanakan, atau oleh pengadilan internasional dengan yurisdiksi yang di terima oleh para peserta konvensi. Konvensi ini dengan jelas menyatakan pelaku genosida maupun yang merencanakan genosida baik mereka adalah pemimpin yang bertanggung jawab secara konstitusional, pejabat publik, atau individu dapat diadili melalui pengadilan di negara terjadinya genosida maupun melalui pengadilan internasional yang memiliki yurisdiksi. Dengan demikian, negara adalah mahluk yang paling bertanggung jawab terhadapkekerasan sipil oleh militer.

Variabel ketiga adalah Human Security yaitu berhubungan dengan pendektan ekonomi, kesehatan yang basisnya adalah pembangunan yang berkelanjutan sesuai dengan visi dan misi UNDP. Wijayanto mengusulkan agar tidak terjadi kelebihan kontrolmiliter terhadap sipil maka hubungan antara sipil dan militer harus di arahkan pada keseimbangan. Dalam konteks ini berhubungan dengan keamanan nasional. Wijayanto mengusulkan 1) harus ada profesionalisme militer dalam ancaman domestikdan eksternal, 2) integrasi institusi nasional, 3) kontrol sipil secara demokratis. Berhubungan dengan isu kekerasan ini menyangkut keamanan nasional Wijayanto juga mengusulkan dimensi keamanan itu harus menyangkut: a) pertahanan negara (politik), b) stabilitas dalam negeri, c) ketertiban publik dan keselamatan insani. Sehingga, apabila. Oleh sebab itulah dalam melihat masalah yang kompleks ini harus ada dewan dalam konteks nasional yang mampu mendefinisikan keadaan negara sehingga pantaskah suatu intervensi militer dilakukan. Bukan definisi keamanan yang disampaikan 
sepihak oleh para biksu dan Aung San Su Kyi. Keamanan nasional ini harus melibatkan multi aktor sehingga tidak ada diskriminasi dan yang paling penting adalah prosedur penyelesaian masalah bukan sebagai monster yang bisa melakukan intervensi sewenangwenang. Oleh sebab itu perlunya kebijakan hirarki agar bisa terarah dalam satu komando.

Andi Wijayanto memisahkan tiga domain dalam kekerasan terhadap sipil. Hal ini di karenakan norma yang beraku dalam setiaptindakan akan berbeda pula terhadapsanksi yang diberikan. Lebih lanjut, apapun dasar argumentasi kekerasan terhadap sipil harusnya bias terkontrol. Negara sebagai unit yang memiliki power politicuntuk mengamankan situasi domestic haarusnya mampu mengontrol angkatan militernya. Hal inilah yang tidak terjadi di Myanmar akibatnya angkatan militer justru menjadi monster yang tidak mampu menjaga stabilitas keamanan nasional. Dampaknya dari tiga modelkekerasan sipil yang telah di jelaskan oleh Wijayanto telah terjadi di Myanmar. Kondisi ini juga melanggar lima prinsip perdamaian internasional yakni 1.Ketertiban, Keadilan, Kesejahteraan, Keamanan dan Kesenjangan (Sorenson, 2014).
Variabel ketiga dari ana- lisis konstruktiviame adalah Communication action. Variabel ini diperkenalkan oleh Nicolas Onouf sebagai salah satu pemikir kontsruktivisme.

Argumentasi dasarnya adalah bahasa yang tersusun oleh kata dan kalimat memiliki makna atau inter subjektif meaning dalam membentuk interkasi simbolik antaraktor. Bahasa menjadi media untuk menyampaikan ide yang masih abstrakdalam alam bawa sadar manusia. Dengan bahasa manusia mampu menterjemahkan atau menyampaikan sesuatu yang diinginkan. Bahasa menjadi perekat untuk memahami satu samalainya. Dalam konteks inilah Communication action yang melibatkan variabel bahasa disebut dengan diplomasi. Sejalan dengan itu Ricard W menjelaskan bahwa merupakan konversi input berupa infromasi tentang apa yang harus dilakukan sebuah negara menjadi output berupa diplomasi atau aliansi/kualisi (2012:411). George Kennan mendefinisikan diplomasi sebagai " an art and international relations in a universal context (Fathun, Paradiplomasi Menuju Kota Dunia: Studi Kasus, 2016). Jadi dapat disimpulkan bahwa diplomasi merupakan upaya 
negara melalui cara berkomunikasi yang baik dengan wakil-wakil yang terpilih untuk merebut ke- pentingan nasional dengan jalan damai. Kemudian di analisis dalam bentuk

(1) speech act (Komunikasi)

(2) Existential Threats (ancaman)

(3) Reference object (referensi) (4) Audience (objek).

Bentuk pertama dari communication action adalah speech act. Speech act dimaknai dengan sesuatu yang disapaikan kepada lawan bicara dala diplomasi terkait asalah yanag di bahas. Kounikasi ini yang keudian disebut dengan diplomasi adalah seni untuk menyampaikan gagasan yang telah dirancang dalam alam bawa sadar manusia.Berhubungan dengan krisis Rohingnya speech act yang dilakukan oleh Menteri Retno adalah menyampaikan bahwa akan dampak yang ditimbulkan oleh tindakan kekerasan terhadap warga Rohingnya. Ancaman tersebut kemudian disebut dengan Existential Threats (ancaman). Ancaman yang di timbulkan oleh adanya kekerasan terhadap etnis Rohingnya secara politik akan mengganggu stabilitas politik dalam negeri bahwkan akan menggangu stabilitas regional. Ancaman tersebut kemudian bisa menjadi bencana sosial di Myanmar yang akan mendatangkan korban jiwa. Lebih lanjut tentunya hal tersebut akan menggangu stabilitas ekonomi, hukum dinegara tersebut. Dengan demikian yang di butuhkan adalah Reference object (referensi) yang menyangkut metode penyelesaian masalah krisis kemanusiaan di Myanmar. Lebih lanjut, krisis ini begitu kompleks bukan hanya terkait rivalitas antara agama namun ada kompleksitas lainya termasuk bidang ekonomi dan keterlibatan trager konflik yaitu Negara-negara di luar kawasan yang mengakselerasi konflik karena memiliki kepentingan ekonomi terhadap wilayah tersebut. terdapat fakta yang menyebutkan bahwa ternyata ada kepentingan Ekonomi Politik atas apa yang menimpa etnis Rohingya tersebut. Myanmar, diperkirakan memiliki cadangan minyak dan gas sebesar 11 triliun dan 23 triliun kaki kubik, hal tersebut membuat perusahaan multinasional asing berebut mendapatkan kesepakatan mengeksplorasinya. Selain itu Myanmar juga berada dalam posisi geo-politik yang menguntungkan, terutama bagi Cina, karena merupakan akses pada laut India dan Laut Andaman https://www.forbes.

com/sites/ericrmeyer/2015/02/09/ oi 1 - a n d - g a s - c h in a - t a ke s - a shortcut/\#7aff1ad17aff. Di akses $20 \mathrm{i}$ 2018). 


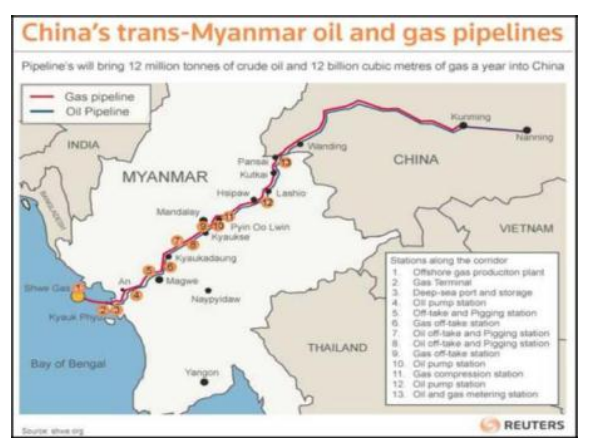

Sumber : google gambar

Melalui jalur (link) tersebut pula, kini memungkinkan Cina mengimpor minyak mentah dari Timur Tengah serta Afrika tanpa harus melewati Selat Malaka dan masuk ke Laut Cina Selatan. Berdasarkan adanya fakta tersebutlah, pengamat politik tidak lagi memandang kasus yang terjadi di Myanmar merupakan sebagai pembantaian etnis biasa, melainkan adanya upaya pemenuhan kepentingan nasional yang dilakukan oleh pemerintah Myanmar itu sendiri. Dengan demikian audience yang dimaksudkan di sini adalah semua stakeholders yang terlibat dalamkonflik baik pemerintah, etnis Rohingnya, intansi militer,PBB maupun Indonseia sebagai mediator harus memberikan sosialisasi penyelesaian masalah yang terbaik. Indonesia bertindak berdasarkan entitas moralitas dengan perhitungan untung rugi untuk menyelesaikan masalah tersebut sehingga geostrategi diplomasi adalah jalan terbaik untuk merangkul semua pihak yang terlibat dalam konflik.

Geostrategi diplomasi akan mempertanyakan tiga hal yakni siapa kita, apa keinginan kita dan bagimana mewujudkankanya. Berhubungan dengan pertanyaan siapa kita, keterlibatan Indonesia jelas sebagai Negara sahabt yang sudah melakukan hubungan bilateral dengan Myanmar sudah sejak lama, sehingga dalam konteks politik bertetangga, apabila tetangga memiliki masalah maka kita ikut serta untuk membantunya. Disisilainya pula dalam konteks regionalism ASEAN kedua Negara adalah Negara besar yang mendirikan ASEAN dan terlibat dalam Konfrensi Asia Afrika. Berhubungan dengan keinginan Indonesia sudah pasti untuk mendamaikan konflik yang terjadi di Myanmar. Keinginan mulia ini tentunya untuk menumpas segala kesalahan komunikasi antaraktor- yang terlibat konflik. Kesalahan komunikasi itu akan menimbulkan dampak mengerikan bagi kelansungan Myanmar sebagai sebuah Negara merdeka. Keinginan lainya adalah Indonseia sebagai Negara demokratis yang memiliki konstitusi untuk ikut serta dalam 
perdamamaian dunia.

Pertanyaan terkahir terkait apa yang dilakukan adalah Indonseia melakukan diplomasi dengan model $4+1$. Mekanisme yang terjadi dalam diplomasi kemanusiaan Indonesia ke Myanmar adalah pada hari pertama Menlu Retno Marsuadi bertemu dengan Panglima Angakatan Bersenjata Myanmar U Min Aung Hlaing bertempat di Naypyidaw. Menlu Retno Marsuadi menyarankan agar upaya meredakan ketegangan yang terjadi di Negara Bagian Rakhine menjadi fokus utama Pemerintah Myanmaar saat itu. Hari kedua Menlu Retno Marsuadi bertemu dengan kepala pemerintah Aung San Suu Kyi dan menyampaikan tujuan utamanya, yaitu usulan formulasi 4+1.

Dikutip dari (Kemlu.go.id: 2017) Menlu RI menyampaikan usulan Indonesia kepada Aung San Suu Kyi yang disebut Formula 4+1 untuk Rakhine State. Empat elemen ini terdiri dari: (i) mengembalikan stabilitas dan keamanan; (ii) menahan diri secara maksimal dan tidak menggunakan kekerasan; (iii) perlindungan kepada semua orang yang berada di Rakhine State, tanpa memandang suku dan agama; dan (iv) pentingnya segera dibuka akses untuk bantuan kemanusiaan. Ditambah satu elemen lain (v) pentingnya agar rekomendasi Laporan Komisi Penasehat untuk Rakhine State yang dipimpin oleh Kofi Annan dapat segera diimplementasikan.

Diplomasi Menteri Luar Negeri RI Retno LP Marsudi membawa formula 4+1 untuk Rakhine State yakni mengembalikan stabilitas dan keamanan; menahan diri secara maksimal dan tidak menggunakan kekerasan; perlindungan kepada semua orang yang berada di Rakhinne State tanpa memandang suku dan agama; dan pentingnya segera dibuka akses untuk bantuan kemanusiaan. Serta 1 elemen adalah pentingnya agar rekomendasi laporan Komisi Penasehat untuk Rakhine State segera diimplementasikan. AKIM sendiri berkomitmen membawa bantuan senilai US\$ 2 juta berbentuk pen- didikan, kesehatan, ekonomi dan relief. Formula yang dibawa juga merupakan hasil dari diskusi panjang dengan semua elemen bangsa. (Dikutip dari Kompasiana. com/7/9/17)

Apa yang dilakukan oleh Menlu RI tentunya tidak lepas dari dirinya sebagai seorang perempuan. Perempuan cenderung peka, sensitif, memiliki rasa kasihan yang tinggi. Kekerasan yang terjadi di Rakhine adalah bentuk pendekatan 
perempuan terhadap masalah itu. Artinya Menlu sebagai seorang muslim dan atau agama apapun tidak akan mengajarkan kekerasan seperti itu. Ditambah lagi dalam konteks Indonesia kebebasan terhadap beragama begitu tinggi. Dengan latar belakang itulah kemungkinan bahwa kekerasan yang terjadi di Rakhine meruapakan kegiatan yang mengerikan.

Di Indonesia dalam menjunjung tinggi kebebasan beragama diatur dalam UU/39/19991 terkhusus pasal 22 yang menyatakan setiap orang berhak memeluk agamanya masingmasing dan beribadah sesuai dengan keyakinan tersebut. Pasal 24 juga menjelaskan Setiap orang berhak untuk berkumpul, berapat, dan berserikat untuk maksud-maksud damai. Begitu juga dalam UUD 1945 terhusus pasal 27, 28 an 29. Hal ini sejalan juga dengan bunyi Pancasila terkhusus sila 1 tentang hak dan kewajiban beragama, sila 2 keadilan yang beradab untuk semua mahluk,sila ke 3 untuk menjaga persatuan dan sila ke 4 tentang kebebaasan berkumpulserta sila ke 5 hak untuk hdiup layak dan dihormati.

\section{KESIMPULAN}

Kasus Rohingnya menjadi bukti kongkrit bahwa keterlibatan
Mentri Luar Negeri Indonesia sebagai mediator adalah bukti kepedulian Indonsia yang demokratis dan respekakan komunitas ASEAN. Sehingga, dalam analisis model kebijakan luar negeri yang dimainakan oleh Mentri Luar Negeri menggunakan pendekatan geostrategi diplomasi. Indonesia menagih janji Myanmar terkait menjunjung tinggi HAM apalagi dalam lingkup regionalism ASEAN baik yang telah di sepakati dalam KAA 1954, 2015 mapun konvensi lainya dalam lingkup regionalism. apa yang dilakukan oleh Mentri Luar Negeri adalah menggunakan strategi akomodasi dan korkondanse. Kedua strategi ini mewakili lingkungan strategis kasus dalam konteks wilayah darat. Dengan menerapkan strategi ini maka output yang diharapkan adalah menyelesaikan dengan menguntungkan satu sama lainya.

Dalam konteks ini berhubungan dengan keamanan nasional. Wijayanto mengusulkan 1) harus ada profesionalisme militer dalam ancaman domestikdan eksternal,

2) integrasi institusi nasional, 3) kontrol sipil secara demokratis. Berhubungan dengan isu kekerasan ini menyangkut keamanan nasional Wijayanto juga mengusulkan dimensi keamanan itu harus 
menyangkut: a) pertahanan negara (politik), b) stabilitas dalam negeri, c) ketertiban publik dan keselamatan insani. Sehingga, apabila. Oleh sebab itulah dalam melihat masalah yang kompleks ini haruss ada dewan dalam konteks nasional yang mampu mendefinisikan keadaan negara sehingga pantaskah suatu intervensi militer dilakukan. Bukan definisi keamanan yang disampaikan sepihak oleh para biksu dan Aung San Su Kyi. Keamanan nasional ini harus melibatkan multi aktor sehingga tidak ada diskriminasi dan yang paling penting adalah prosedur penyelesaian masalah bukan sebagai monster yang bisa melakukan intervensi sewenangwenang.Oleh sebab itu perlunya kebijakan hirarki agar bisa terarah dalam satu komando.

Di sisi lainya kehadiran Menlu RI dalam penyelesaian masalah di Myanmar merupakan suatu langkah kongrit dengan diplomsi 4+1 yang di mana mampu meredam kekerasan di Rakhine. Hal ini tentunya sudah melanggar tiga model yang disampaikan di atas tentang kebebasan manusia. Menlu RI yang seorang perempuan tentunya memiliki sensitifitas yang kuat dan peka akan masalah ini. Hal ini menyangkut hajad hidup orang banyak dan perempuan adalah mahluk yang palaing merasa ngeri dengan kekerasaan. Dengan jiwa keperempuanan Menlu RI dan Aung San Su Kyi bisa meredam masalah ini dengan baik. Perlu dipahami bahwa kekerasan terhadap manusia sampai pada genosida bukanlah hal yang baik bagi negara manapun dan tidak akan di ajarkan oleh agama manapun.

Diplomasi merupakan aplikasi dari pemikiran konstruktvisme yang selalu mengutamakan kesa- daran akal dan keutamaan moral untuk menaati norma nasional dan internasional. Diplomasi adalah artikulasi dari Negara dalam memaknai pentingnya- pendekatan komunikasi- dengan mengutamakan bahasa sebagai media saling memahami. Kontruktivisme selalu mengutamakan tiga hal dasar ide, norma dan bahasa dalampolitik internasional. Apa yang dilakukan oleh Indonesia melalui Menteri Luar Negeri adalah bukti pe- mikiran konstruktivisme di mana dengan pendekatan ini mampu memperlihatkan keberhasilan Indonsia menjadi mediator konflik. Dengan identitas, personal sebagai perepuan, Negara beradab, Negara beragama dan Negara demokrasi pendekatan Indonesia mampu menarik perhatian internasional. Disisilainya identitas peran sebagai 
sesama Negara ASEAN dan peran sebagai sesama manusia Indonesia merasa perlu terlibat dalam krisis tersebut sebagai bukti konstitusional. Lebih lanjut identitas kolektif di mana kedua Negara adalah sahabat dan satu regionalism dan tetunya memiliki perjuangan yang sama ketika masa-masa kemerdekaan yaitu Konfrensi Asia Afrika. Hubungan bilateral yang terjalin antarkedua Negara mungkin saja menjadi pemicu keterlibatan Indonseia disambut baik oleh pihak Myanmar untuk menyelesaikan masalah.

Sehingga,dengan pendekatan norma dan bahasa komunikasi mampu meredam krisis kemanusiaan di Rohingnya.Hasil positifnya adalah Indonesia dengan geostrategic diplomasi mampu menjadi mediator yang mampu mengurai masalah dengan netral. Keterlibatan Indonesia sebagai Negara demokrasi perlu diapresiasi sebagai bentuk dari implementasi Politik Luar Negeri Indonesia dengan menggunakan strategi, akomodasi dan kokondans. Oleh sebab itulah, peristiwa ini akan menaikan citra Indonesia sebagai Negara mediator unggul dalam menciptakan perdamaian dunia sesuai dengan konstitusinya. Peristiwa ini akan menjadikan
Indonesia sebagai Negara yang memiliki kualitas diplomasi yang unggul dan diperhitungkan dalam dunia internasional.

\section{Bibliography}

Abi Hara, Abu Bakar. Pengantar Analisis Politik Luar Negeri, Dari Realisme Samapi Konstruktivisme, Bandung: NUANSA, 2011.

Carlesnaes, Walter, DKK. Handbook Hubungan Internasional,

Bandung: Nus Media, 2013.

Hanrieder, Wolfram, Comparative Foreign Policy, Theoretical Essay: David Mc. Kay New York: Company,Inc. 1971.

Hudson, V,M., The History and Evolution of Foreign Policy Analisys . In S. Smith, A. Hadfield \& T. Dunne, (Eds), Foreign Policy: theories, actors, cases, Oxford. : Oxford. University Press, 2008.

Carlesnaes, W. (2013). Handbook Hubungan Internasional Terjemahan. Bandung: Nuansa.. K, J. H. (1988). Politik Internasional Kerangka Untuk Analisis. Jakarta: Erlangga.

L.M.Fathun. (2017). KEBIJAKAN I D E O S I N K R E T I K ( W HO L I ST IC ) J O KO WIDODO (JOKOWI) DALAM 
KONPERENSI ASIA AFRIKA TAHUN 2015. Jurnal Dinamika Global, cVol. 2(02),42-67.

Laode, M. F. (2016). Kebijakan Geopolitik Poros Maritim Di Era Jokowi. Yogyakarta: Tesis MIHI UMY.

Burchil , Scott dan Andew Linklater (2005). Teori-Teori Ilmu Hubungan Internasional Trjhn. Bandung: Nusa Media. Mas'oed, M. (1994). Ilmu Hubungan Internasional , Disiplin dan Metodologi. Jakarta: LP3S.

McClelland, C. ( 1981). Ilnmu Hubungan Internasional , Teori dan Sistem. Jakarta: CV Rajawali.

Onuf, N. (1989) . World of Our Making: Rule in Social Theory and International Relations . Columbia: University of South Carolina Press.

Rosyidin, M. (2015). The Power of Ideas: Konstruktivis dalam Studi Hubungan Internasional,. Yogyakarta: Tiara Wacana.

Robert, Jacson dan Georg Sorenson. (2014). Pengantar Studi Ilmu Hubungan Internasional Edisi
Revisi. Yogyakarta: Pustaka

Pelaajar.

Tovy, T. (2015). The Changing Nature of Geostrategy. Albana: Air University Press Air Force Research Institute.

Venus, Antar. ( 2015). Fisafat Komunikasi Orang Melayu .: Indonesia: Simbiosa

Rekatama Media.

Warsito, T. (1998). Teori-Teori Politik Luar Negeri, Relevansi dan Keterbatasanya. Yogyakarta: BIGRAF Publishing.

Wendt, A. (1992). , Anarchy is What State Make of It: The Social Construction of PowerPolitict, International Organization. Vol. 46, No.2391-425. 